\title{
‘Cornwallism' and Arguments against Greenhouse Gas Emissions Reductions
}

\section{Karin Edvardsson Björnberg, Helena Röcklinsberg, Per Sandin}

\begin{abstract}
Opposition against greenhouse gas emissions reductions is strong among some conservative Christian groups, especially in the United States. In this paper, we identify five scripture-based arguments against greenhouse gas mitigation put forward by a core group of Christian conservatives ('the Cornwallists'): the anti-paganism argument, the enrichment argument, the omnipotence argument, the lack of moral relevance argument, and the cost-benefit argument. We evaluate to what extent the arguments express positions that can be characterized as climate science denialist and to what degree they are consistent with support for climate adaptation. Using Stefan Rahmstorf's (2004) taxonomy of climate science denial, we conclude that the Cornwallists could be labelled climate change deniers. However, their opposition is not only based on denial of climate science but often rests on premises that render the science irrelevant, a position we term 'relevance denialism'.
\end{abstract}

Keywords: Christianity, climate change, denial, Cornwall Alliance, evangelical 


\section{Introduction}

Considering the dire impacts of climate change on humans and the environment, it comes as no surprise that Christian leaders and organizations have been and are among the most dedicated defenders of greenhouse gas mitigation. ${ }^{1}$ Prominent leaders from many Christian denominations, among them Pope Francis and the Ecumenical Patriarch Bartholomew of Constantinople, have publicly defended climate science and lent their support to emissions reductions (Pope Francis, 2015; Ecumenical Patriarch Bartholomew, 2016; see also Haag, 2006; Chryssavgis, 2007; Agliardo, 2014; Mongrain, 2017). However, the support for climate action is far from unqualified among Christians, and the issue of climate change constitutes a theological as well as moral, political and epistemological battleground (Kearns, 2007). Studies from the United States (US) and Australia show that opposition against greenhouse gas mitigation is particularly strong among white evangelical Protestants (Pew Research Center, 2015; see also Smith and Leiserowitz, 2013; Morrison et al., 2015). ${ }^{2}$ It is not unreasonable to speak of a backlash from American evangelicals, since 'climate skepticism now appears to have been more deeply anchored as a part of evangelical identity' (Bean and Teles, 2015: 2).

In the US, the Cornwall Alliance for the Stewardship of Creation is at the center of the opposition against climate action. Founded in 2005, the Alliance is a coalition of predominantly evangelical leaders who support 'biblical earth stewardship' based on the principles of the Cornwall Declaration on Environmental Stewardship. The national spokesperson for the Alliance is its founder E. Calvin Beisner, a long-time conservative

\footnotetext{
${ }^{1}$ Similar initiatives engage members of religions other than Christianity (Kearns, 2007; Schaefer, 2014).

${ }^{2}$ It has been suggested that this holds true also for some conservative Catholic groups (Lieberman, 2012; Mirus 2007, 2012).
} 
critic of the Christian left (Bean and Teles, 2015: 6). The group opposes greenhouse gas emissions reductions on moral, theological, political, and what the group claims to be scientific grounds, and their efforts have been largely successful. Opposition from the Cornwall Alliance contributed to quelling the efforts of the mid-2000s Evangelical Climate Initiative to establish 'climate care' as a core concern for evangelicals, and the Alliance has been instrumental in establishing a strong link between the evangelical community and the US Republican Party (Bean and Teles, 2015).

Despite the important role played by the Cornwall Alliance and other conservative Christian groups in American climate and environmental politics, the actual arguments put forward by those groups have hitherto received relatively sparse academic attention. In this paper, we aim to address this research gap. Below, we analyze the arguments that have been put forward against climate action by a 'core' of conservative Christian (predominantly evangelical) leaders and scholars, in policy documents, bible commentaries and editorials. ${ }^{3}$ The identified arguments should not be taken to represent what all (or even most) conservative Christians argue, and even less, what they actually believe. ${ }^{4}$ Our main focus is on the positions expressed by the Cornwall Alliance and actors associated with the Alliance. ${ }^{5}$ There are two reasons for having this narrow focus: First, as mentioned above, the Alliance has been instrumental

\footnotetext{
${ }^{3}$ We understand 'evangelical' as referring to theologically conservative Protestants, that is, faith groups that satisfy David W. Bebbington's (1989) criteria of: conversionism, activism, biblicism, and crucicentrism.

${ }^{4}$ For an extensive elaboration, see Wilkinson (2012).

5 The term 'associated actors' is admittedly vague. In this paper, it will be used to refer to those organizations and individuals who have publicly endorsed the views of the Cornwall Alliance, for instance by signing the Cornwall Declaration, and organizations constitutive to the formation of the Alliance, such as the Acton Institute for the Study of Religion and Liberty.
} 
in the political reaction against initiatives in favor of climate action in evangelical circles (Bean and Teles, 2015). Second, the arguments presented by the Cornwall Alliance are clearly stated and thus allow systematic scrutiny. For brevity, we will refer to the proponents of the arguments discussed here as 'the Cornwallists', while not implying that all of them are formally affiliated with the Cornwall Alliance.

We identify five partly overlapping arguments against greenhouse gas mitigation forwarded by the Cornwallists, summarized under the following headings: the antipaganism argument, the enrichment argument, the omnipotence argument, the lack of moral relevance argument, and the cost-benefit argument. All arguments are scripturebased in the sense that they are supported by some interpretation of the Bible, although, as will be argued below, similar arguments have been raised in secular contexts, too.

We then analyse the arguments on the basis of the following research questions: First, to what extent do the identified arguments express positions that can be characterized as climate science denialist? Or, to what extent do the arguments build on premises that have been refuted by scientists?

Second, in what ways do the arguments differ from arguments against greenhouse gas mitigation put forward in secular contexts? The arguments that have secular counterparts are of particular interest, since they point to areas where the Cornwallists (and perhaps other conservative Christians) and secular opponents of greenhouse gas mitigation share interests. This means that they provide potential for new alliances and, thus, concerted action against proposed climate policy measures - an example of 'strange bedfellows' (Bean and Teles, 2015). Whether or not such alliances might be successful is beyond the scope of the present paper.

Third, to what extent are the arguments consistent with support for climate adaptation action? Even if greenhouse gas mitigation is generally opposed by the 
Cornwallists, it remains to be investigated if the arguments could be consistent with a more positive attitude to climate adaptation. If they are, this could present an opportunity to involve conservative Christian groups - though likely not core ones like the Cornwallists - if not in greenhouse gas mitigation, then at least in the adoption and enforcement of risk-reducing adaptation measures.

Section 2 briefly outlines four types of climate science denial identified in the academic literature. In Section 3, we summarize the five arguments against greenhouse gas emissions reductions put forward by the Cornwallists. In Section 4, we investigate the extent to which the identified arguments build on premises that contradict or deny established climate science. Section 5 determines how the five arguments differ from similar arguments put forward in secular contexts. Section 6 investigates whether the arguments are reconcilable with a more positive attitude towards climate adaptation. Section 7 contains our conclusions.

Although the paper deals with theological and scientific issues related to climate change, we do not offer any independent interpretations of the Bible, nor do we evaluate the scientific evidence of global warming. Instead, our objective is to give an as accurate analysis as possible of the scripture-based arguments against greenhouse gas mitigation put forward by some influential conservative Christian groups, while investigating whether there are possible points of consensus between faith and non-faith communities over the issue of climate change.

\section{Types of climate science denial}

Climate science denial has received considerable academic attention in the last decade, with an emphasis on the actors involved, the arguments and strategies used, and the factors behind its presence in the public debate (Edvardsson Björnberg et al., 2017). In 
the literature on climate science denial, different categories of denial are identified. ${ }^{6}$ Stefan Rahmstorf (2004) distinguishes between 'trend, 'attribution', and 'impact' denial (see also Poortinga et al., 2011; Matthews, 2015). The three categories of denial correspond to the three basic tenets of climate science set out in the reports of the Intergovernmental Panel on Climate Change (IPCC), namely: (1) warming of the climate system is unequivocal; (2) human influence is the dominant cause of the observed warming; and (3) continued warming of the climate system will have profound negative impacts on humans, societies and the environment (IPCC, 2014).

Trend denial, thus, involves denying the fact that any significant warming is taking place at all. This can, for example, be done by questioning the reliability of the temperature record, for instance with arguments referring to weather stations being placed in poor locations, or to data records allegedly showing that Antarctica is not melting but instead gaining ice.

Attribution denial, in contrast, does not necessarily involve any explicit denial of the fact that the climate is warming, but instead questions whether human activities are responsible. Some attribution skeptics deny that the rise in carbon dioxide levels is anthropogenic, but instead explain the increase by referring to natural processes such as release of carbon dioxide from the oceans. Others agree that human activities contribute to increasing atmospheric carbon dioxide levels but argue that the contribution is insignificant.

Impact denial, finally, involves denying that global warming could give rise to any significant negative impacts on humans or the environment. In addition to questioning the allegedly flawed models upon which predictions of climate impacts are

\footnotetext{
${ }^{6}$ The website 'Skeptical Science' contains a list of climate skeptic arguments by taxonomy along with rebuttals, http://www.skepticalscience.com (accessed 30 January 2019).
} 
based, impact denialists emphasize the expected positive consequences of climate change, such as potentially increased agricultural production in higher latitudes, or they argue that animals, humans and societies have (and always have had) an ability to adapt to climate change.

A fourth category of denial could be added to the trend-attribution-impact framework, namely denial of scientific consensus (Engels et al., 2013; McCright et al., 2016). Consensus denial involves questioning the existing consensus among climate scientists about the abovementioned conclusions drawn by the IPCC. ${ }^{7}$ It can take different forms. Some deny altogether that there is scientific consensus on climate change; others acknowledge that there is consensus but argue that it is based on illegitimate evidence. ${ }^{8}$

In this paper, we argue that the introduction of a term for yet another category might prove illuminating: relevance denialist arguments. These arguments do not necessarily deny the science but introduce premises into the argument that render the science irrelevant.

\section{Scripture-based arguments against greenhouse gas mitigation}

Below, five arguments forwarded by the Cornwallists to defend a business-as-usual approach to climate change are analysed: the anti-paganism argument, the enrichment

\footnotetext{
${ }^{7}$ A meta study of consensus studies, performed by John Cook and colleagues, showed that 'the consensus that humans are causing recent global warming is shared by $90 \%-100 \%$ of publishing climate scientists' (Cook et al., 2016: 1).

${ }^{8}$ See 'The Pillars of Climate Change Denial', http://ncse.com/library-resource/pillars-climate-changedenial (accessed 30 January 2019).
} 
argument, the omnipotence argument, the lack of moral relevance argument, and the cost-benefit argument. ${ }^{9}$

\section{The anti-paganism argument}

The anti-paganism argument says that putting the environment, including the climate system, at the centre of one's attention, by working intensely towards greenhouse gas emissions reductions is wrong since it serves 'the creature rather than the Creator' (Romans 1:25). It constitutes a form of pantheism or neo-pagan nature worship that conflates the transcendent supernatural God with the natural worldly order (Danielsen, 2013; Daley Zaleha and Szasz, 2015).

The argument builds on two beliefs that are shared among many Christians. The first belief is that a metaphysical dichotomy exists between God (the supernatural) and his creation (the natural order). Thus, the Cornwall Alliance (2013) argues that God 'is, always has been, and always will be absolutely distinct from and transcendent over creation, which He rules at all times and places'. The second belief is that it is right to worship God but wrong to worship the environment. Although most Christians agree that humans have some responsibility for the environment, or Creation, the Cornwallists consider it wrong to let such considerations occupy a too prominent standing among one's set of goals, or values. In their view, caring intensely about the environment amounts to worshiping it instead of being a prudent steward of it.

\footnotetext{
${ }^{9}$ In the following, citations from the Bible will be taken from the English Standard Version (ESV).
} 
Support for the Creator/creation dichotomy and its moral implications can be found in policy documents and newspaper articles published by Cornwallists. The Cornwall Alliance (2013) elaborates:

\footnotetext{
We deny atheism (there is no God), pantheism (everything is God), panentheism (God is to the universe as the human soul is to the human body), animism (there are many gods, and they indwell and animate physical objects as human souls indwell and animate human bodies), and any other view that denies the Creator/creature distinction, because those who hold them exchange the truth about God for a lie and worship and serve the creature rather than the Creator, who is blessed forever (Romans 1:25).
}

In an article entitled 'Gospel Confusion in Christian Environmentalism', published in the conservative Christian periodical World, Cornwallist E. Calvin Beisner (the national spokesman for the Cornwall Alliance) argues that environmentalism is problematic not only because it blurs the metaphysical dichotomy between the natural and the supernatural, but because it conflates Divine law with the gospel (Beisner, 2012). Although taking good care of the earth is part of the law and, thus, an obligation (what God requires us to do), it must not be conflated with the gospel, that is, giving life (what God has done). The divine law and the moral imperatives incorporated into it must not be equated with grace (the gospel), since only the latter can lead to Salvation.

The core point is, of course, whether greenhouse gas emissions reductions ought to count as 'prudent stewardship' or deification of nature. The Cornwallists tend to believe the latter, whereas many other evangelical Christians consider climate action to belong to the former category (Wilkinson, 2012).

\section{The enrichment argument}

The enrichment argument says that restricting human welfare-generating activities through the enactment of environmental regulations, for example greenhouse gas 
emissions reductions, is wrong, since it conflicts with man's elevated standing in the creation. As bearer of God's image (Genesis 1:26-27), it is man's responsibility and right to improve nature and exercise 'dominion over the fish of the sea and over the birds of the heavens and over every living thing that moves on the earth' (Genesis 1:28, see also Psalm 115:16). This is said to include a responsibility and a right to extract and burn fossil fuels.

Many Christians understand the Genesis creation as an ascending spiritual hierarchy, which begins with the creation of the inanimate and culminates the in the creation of humans (Nagle, 2008). Humans, and humans only, are bearers of God's image and are therefore closer to God than their fellow creatures. This has two moral implications. First, it makes humans more valuable than the rest of the creation. Consequently, the Cornwall Alliance (2013) denies that 'any other terrestrial life form bears the image of God or is of equal value or priority with human beings (Matthew 10:29-31)'. Moreover, the elevated standing of humans conveys to them particular rights and responsibilities in relation to the rest of the creation. The dominion injunction (Genesis 1:28) informs much of the Christian environmental stewardship agenda, such as the 'creation care' thinking of the National Association of Evangelicals (NAE, 2015; see also Christianity Today, 2008, ECI, 2006 and Lausanne Movement, 2011). However, for the Cornwallists, 'dominion' takes on a particular meaning. It is not about protecting the environment from encroachment; instead, it involves transforming the natural world to enrich creation and human well-being (Beisner, 1997; McCammack, 2007). ${ }^{10}$ This is explicit in the Cornwall Declaration:

\footnotetext{
${ }^{10}$ For a similar line of thought in the Catholic tradition, pointing at the fulfillment of a created being through Adam giving it a name and thereby a meaning, see Schlitt (1992).
} 
Our position, informed by revelation and confirmed by reason and experience, views human stewardship that unlocks the potential in creation for all the earth's inhabitants as good. Humanity alone of all the created order is capable of developing other resources and can thus enrich creation, so it can properly be said that the human person is the most valuable resource on earth. (Cornwall Alliance, 2000)

One way of transforming the natural world to enrich creation is to utilize natural resources in order to meet human needs:

\begin{abstract}
We affirm that one way of exercising godly dominion is by transforming raw materials into resources and using them to meet human needs. (Cornwall
\end{abstract} Alliance, 2013)

We affirm that God placed minerals, plants, and animals in and on the Earth for His pleasure, to reveal His glory and elicit man's praise, and to serve human needs through godly use (Genesis 2:5-16; 4:22; Numbers 31:21-23; Job 38-41; Psalm 19:1-6; Psalm 104). (Cornwall Alliance, 2013)

Underlying this interpretation of the 'dominion injunction' is a theological construct that distinguishes between 'the garden' as a divinely ordered place and wilderness, which is the result of Adam and Eve's sin, as well as the consequent destruction of the Garden of Eden. God put Adam and Eve in the Garden of Eden and instructed them 'to work it and keep it' (Genesis 2:15). Hence, in order to return to that blessed state, man must act; he must seek to transform cursed ground - the wilderness - into a garden (Beisner, 1993, 1997; see McCammack, 2007 for a discussion). Only through active human participation, i.e. transformation of nature, can the earth be blessed and made fruitful again. ${ }^{11}$ Further, this theological ground for continuous transformation of nature for the

\footnotetext{
${ }^{11}$ Again, this can be found also in Catholic tradition, see Schlitt (1992). For an interesting discussion on how some of these themes have played out in US history, see Purdy (2015).
} 
benefit of humans is, today, essentially interpreted in economic terms, arguing that only through such progress will humans be able to live well and flourish.

\section{The omnipotence argument}

The omnipotence argument says that, since the earth is God's divine creation it is capable of withstanding environmental pressures, including deforestation, desertification and global warming (Nagle, 2008). Although such events may temporarily upset the earth's stability, it will eventually return to some divine homeostasis. Consequently, there is no reason to worry about climate change or environmental degradation. Support for the argument has been expressed by the Cornwall Alliance (2013):

We affirm that the Earth and all its physical and biological systems are the effects of God's omniscient design, omnipotent creation and faithful sustaining, and that when God completed His creative work it was "very good" (Genesis 1:31).

We deny that an infinitely wise Designer, infinitely powerful Creator, and perfectly faithful Sustainer of the Earth would have made it susceptible to catastrophic degradation from proportionally small causes, and consequently we deny that wise environmental stewardship readily embraces claims of catastrophe stemming from such causes.

We affirm that by God's design Earth and its physical and biological systems are robust, resilient, and self-correcting. We deny that they are fragile.

The argument is elaborated on by Beisner, who adds:

Just as good engineers build multiple layers of protection into complex buildings and systems, so also the wise Creator has built multiple self-protecting and self-correcting layers into His world. Positive and negative feedback mechanisms often minimize or quickly repair environmental damage. Irreversible, catastrophic damage is rare to nonexistent in the world's history. (Beisner, 2005: 13) 
To further the argument, Beisner points to the explicit promise made by God to Noah never again to 'strike down every living creature as I have done' (Genesis 8:21), that is, destroying the earth with a flood. For as long as the earth remains, he has promised that 'seedtime and harvest, cold and heat, summer and winter, day and night, shall not cease' (Genesis 8:22). God's superintending hand, Beisner concludes, gives us good reasons to remain sceptical of the arguments forwarded by secular environmentalists, including the argument that we need to cut down on greenhouse gas emissions in order not to destabilize the earth's climate system.

Support of the omnipotence argument has been found in empirical studies of evangelical Christians in the US. In a study of how evangelicals from two Baptist churches frame their relationship with the environment, several respondents emphasized that God has made the Earth 'pretty resilient' and that 'He can handle a few degrees' (Peifer, Howard Ecklund and Fullerton, 2014: 385-386). According to the interviewed respondents, those circumstances give humans good reasons not to worry about global warming (see also Carr et al., 2012).

\section{The lack of moral relevance argument}

The lack of moral relevance argument says that it is wrong to focus on greenhouse gas mitigation, since there are more pressing issues that warrant the attention of Christians, such as abortion, gay marriage, human trafficking, and not the least, poverty (Danielsen, 2013). Some Cornwallists even believe that the effort to re-direct attention away from these issues to climate change and environmental degradation is Satan's attempt to 'divert [Christians] from their primary mission', namely to spread the Gospel (Nagle 2008: 78). In an article by Bob Allen (2007), published on the website of Ethics Daily, the Southern Baptist pastor Jerry Falwell is quoted saying: 
If I decide here as the pastor and our deacons decide that we're going to get caught up in the global warming thing, we're not going to be able to reach the masses of souls for Christ, because our attention will be elsewhere [...] That's pretty wise for Satan to concoct. ${ }^{12}$

The view that climate policies are the tool of Satan is not endorsed by the Cornwall Declaration or, to the authors' knowledge, defended in any other policy document issued by the Cornwall Alliance. However, the Alliance distinguishes between environmental concerns that are 'well founded and serious' and those that are 'without foundation or greatly exaggerated' (Cornwall Alliance, 2000). Among the former are human health problems that arise from inadequate sanitation, certain agricultural and industrial practices, and the disposal of nuclear and other hazardous wastes in nations lacking adequate regulatory safeguards. Among the latter are global warming and species loss. ${ }^{13}$

Many of the Cornwall Alliance's policy documents stress poverty alleviation, and climate policy is frequently depicted as conflicting with the efforts to combat poverty. In the conservative evangelical press, poverty alleviation has been presented as something that humans are responsible for addressing, while saving the earth is considered God's business (Cheaney, 2016). Biblical support for poverty alleviation is drawn from several passages in the Bible, such as Galatians 2:10, in which the Apostle Paul says: 'Only, they asked us to remember the poor, the very thing I was eager to do.' Galatians 2:10 is cited in the introduction of the Cornwall Alliance's Open Letter (2006)

\footnotetext{
${ }^{12}$ See also Roberts (2007) and Reed (2007).

${ }^{13}$ This is to be contrasted with the view of the NAE, according to which anthropogenic climate change is likely 'the most serious and urgent challenge faced by the physical world now' (NAE, 2015).
} 
to the signers of the ECI's initiative 'Climate Change: An Evangelical Call to Action' and is further elaborated on in Beisner et al. (2006).

\section{The cost-benefit argument}

The cost-benefit argument says that, even if climate change is problematic from a moral point of view, thus deserving some attention from the Christian community, the economic costs of greenhouse gas emissions reductions grossly exceeds the expected benefits. Therefore, Christians should not support climate change action.

Developing this position, E. Calvin Beisner argues that the costs of climate mitigation are substantial and will be borne by people living today. One should tread carefully before imposing such costs on people. Quoting Luke 14:28-32 Beisner calls on evangelical Christians to 'think prudently' and to 'count the cost':

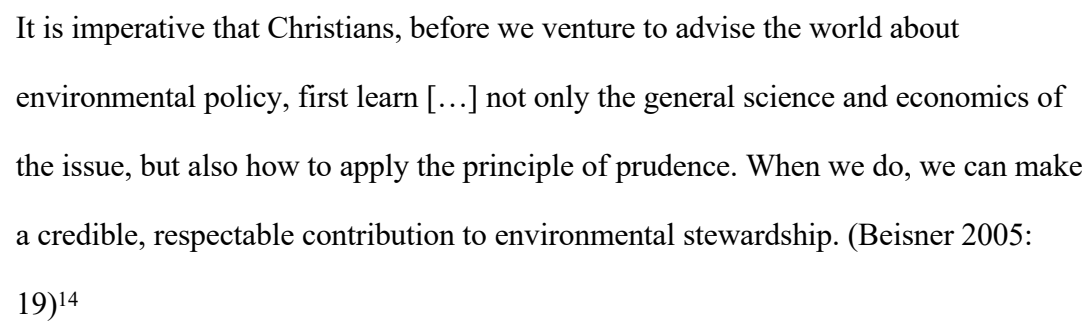

At the same time, the benefits of action are, in Beisner's view, uncertain. The Cornwall Alliance affirms that the concerns over global warming are 'speculative', 'unfounded or undue', and that the risks to human health caused by such warming are 'low and largely hypothetical' (Cornwall Alliance, 2000). In a recent document, the Cornwall Alliance emphasizes that climate change is 'driven primarily by variations in non-human forces', that its human contribution is highly uncertain, and that the benefits of continued fossil fuel use in food production and poverty alleviation outweigh the risks involved

\footnotetext{
${ }^{14}$ See also the Cornwall Alliance (2013): 'We affirm that cost/benefit analysis (Luke 14:28) is a proper and critically important aspect of godly dominion over the Earth (Proverbs 14:4)'.
} 
(Cornwall Alliance, 2019). In summary, the Cornwall Alliance concludes, 'the harm caused by mandated reductions in energy consumption in the quixotic quest to reduce global warming will far exceed its benefits' (Cornwall Alliance, 2006: 2). ${ }^{15}$

\section{Are the scripture-based arguments climate science denialist?}

Our first analytical task was to investigate the extent to which the identified arguments express positions that can be characterized as climate science denialist, that is, build on premises that are contrary to climate science. Of the five arguments identified in this paper, the cost-benefit argument is the argument that most evidently conflicts with climate science. According to the Cornwallists, the reason why we should not do anything about climate change is that the expected costs of greenhouse gas mitigation are substantial and would significantly derail economic progress, while the benefits to be gained are small. Moreover, the human contribution to global warming, if such warming exists at all, is highly uncertain.

These conclusions clearly contradict the key findings of climate science. In the Fifth Assessment Report, the IPCC concludes that global warming will increase 'the likelihood of severe, pervasive and irreversible impacts for people and ecosystems' (IPCC 2014: 8). According to the IPCC, 'it is very likely that heat waves will occur more often and last longer, and that extreme precipitation events will become more intense and frequent in many regions' (p. 10). Thus, the effects of global warming are not small or hypothetical. Furthermore, the IPCC concludes that humans have had a clear influence on the climate system; it is extremely likely that greenhouse gas emissions, driven by economic and population growth, are 'the dominant cause of the observed warming since the mid-20th century' (p. 4). Mitigating the risks of climate

\footnotetext{
${ }^{15}$ See also Cornwall Alliance (2013), sections 22-25.
} 
change would, in their view, require 'substantial and sustained reductions in greenhouse gas emissions' (p. 8).

Using the analytical framework presented in Section 2, it could be argued that the position of the Cornwallists represents all types of climate science denial: trend, attribution, impact, and consensus denial. Holding that the risks caused by global warming are small and hypothetical either denies the phenomenon of global warming altogether (trend denial), or denies that global warming will have a significant impact on people and ecosystems (impact denial), whereas maintaining that the human contribution to global warming is highly uncertain represents attribution denial. In addition, their claims on the magnitude of scientific uncertainty and of an alleged lack of scientific consensus, as expressed in many policy documents published by the Cornwall Alliance, not the least about the role of human activities, amount to consensus denial.

The lack of moral relevance argument says that it is wrong to focus on climate change and greenhouse gas emissions reductions, since there are more pressing moral issues to focus on, among them poverty. Although science is silent on the issue of which moral values and goals ought to be at the centre of a true Christian life, framing greenhouse gas emissions reductions as standing in opposition to poverty eradication in the way the Cornwallists do is inconsistent with a scientific understanding of how poverty and climate change are related, at least unless a very short time horizon is used. One of the key conclusions of the IPCC's Fifth Assessment Report is that the impacts caused by changes in climate will constitute a main driver of poverty and poverty- 
induced migration in the future (IPCC, 2014). ${ }^{16}$ The IPCC writes: 'climate change impacts are projected to slow down economic growth, make poverty reduction more difficult, further erode food security and prolong existing and create new poverty traps' [...] and 'increase displacement of people' (IPCC, 2014: 16). Therefore, it seems plausible to label some of the premises upon which the lack of moral relevance argument is based as impact denialist.

The omnipotence argument conflicts with modern climate science because there is little scientific evidence to suggest that the current changes in climate are but a temporary perturbation, or that the global warming trend will be interrupted regardless of what humans decide to do in the future. From a scientific point of view, there is nothing to suggest that the earth is capable of withstanding environmental pressures. Therefore, the argument could be characterized as trend, attribution, impact and consensus denialist. However, science cannot conclusively disprove the claim that God's intervening hand will not at some point in the future put all things right again. It could thus be objected that it is somewhat misleading to say that the omnipotence argument expresses a climate science denialist attitude, since from the viewpoint of Cornwallists, faith takes precedence over science. ${ }^{17}$ The Cornwall Alliance is explicit about this fact:

\footnotetext{
We affirm that the Bible - the 66 books of the Old and New Testaments - is the sole, absolute, inerrant epistemological basis for mankind for all knowledge of all things, seen
}

\footnotetext{
${ }^{16}$ These conclusions are affirmed by some evangelical groups. In ECI (2006: 2) it is argued that 'the consequences of global warming will therefore hit the poor the hardest, in part because those areas likely to be significantly affected first are in the poorest regions of the world'.

${ }^{17}$ Furthermore, as a more moderate Christian, you could very well accept the scientific evidence for human-induced climate change, including its projected impacts, and still believe that God will at some point put all things right again.
} 
and unseen, and that all claims of truth and moral duty that contradict it are false and harmful. We deny that the physical universe and human observations of it justify truth claims contrary to those of the Bible [...]. (Cornwall Alliance, 2013)

Finally, the anti-paganism and enrichment argument are predominantly theological in that they build on certain beliefs about man's relationship to God and to the creation. Science, including climate science, tells us a lot about the relationships that exist in nature, between humans and other living animals and how human activities affect the environment, but does not take a position on existential issues, such as human's place in a perceived divine order, or on what he or she may or may not do as a member of such an order, at least not on a conventional understanding of science.

To sum up, some of the arguments are denialist and fit neatly in Rahmstorf's categorization. Others, however, do not necessarily deny the science but introduce premises to the effect that the science is rendered irrelevant. ${ }^{18}$ Therefore, it might be more accurate to conceive of them as a separate category - we might call them relevance denialist.

In the climate discussion, many arguments have the following form: From some factual premise(s) F plus some (often relatively uncontroversial) value statement(s) V, some normative conclusion(s) $\mathrm{N}$ can be inferred. The factual statements typically belong to climate science. For instance:

(F1) Human activities cause climate change

(F2) Climate change results in significant environmental perturbation

(V) Significant environmental perturbation is bad, thus

\footnotetext{
18 The authors would like to thank an anonymous referee, who pointed us in this direction.
} 
(N) Something ought to be done about anthropogenic climate change

A trend denialist denies both F1 and F2, whereas an attribution denialist targets F1 and an impact denialist targets F2. This contrasts with a relevance denialist, who denies (or at least questions $\mathrm{V}$ ), thus undermining the support for $\mathrm{N}$. The argument above is, of course, simplified, and a lot of additional unstated premises are involved. Dashed line indicates that the argument is not deductively valid.

The following illustration gives an overview of the conceptual landscape of the climate denialist arguments.

[Figure 1 approximately here.]

\section{Secular counterparts}

The five arguments analysed in this paper are scripture-based, that is, they are based on interpretations of certain passages from Genesis, Exodus and Romans (the antipaganism, enrichment and omnipotence argument), as well as Galatians (the moral relevance argument) and Luke (the cost-benefit argument). This distinguishes them from secular arguments put forward against greenhouse gas mitigation. However, as will be shown, there are some similarities between the scripture-based and arguments based on a secular world view. This applies to all arguments with the possible exceptions of the anti-paganism argument, which appears to be strictly theological with no apparent secular counterparts.

The enrichment argument bears a resemblance to secular anthropocentrism, that is, the idea that only humans, or something specifically human, is non-instrumentally valuable. This idea underlies much of today's environmental and climate policy, although biocentric and ecocentric perspectives are also present. The difference between 
the enrichment argument and secular anthropocentrism is the source of the value. For the Cornwallists, the ultimate source of man's value is his elevated standing in the creation, as being created in God's image. Secular anthropocentrists point to other sources for humanity's privileged axiological position, such as a human being's possession of a higher faculty of rationality.

In a more general sense, the ideas of human progress and enrichment advocated by the Cornwallists fit in well with calls for economic growth, deregulation and development of natural resources made by secular groups belonging to, for instance, the 'wise-use' movement (Kearns, 2007; 2011). ${ }^{19}$ The implicit faith in free enterprise and capitalism as guarantors of economic growth and human development shared by religious and secular actors within these movements provide incentives for - and have indeed been constitutive to - forming new alliances with respect to climate change opposition, such as that between conservative evangelicals and the US Republican Party (Bean and Teles, 2015).

The omnipotence argument says that climate action is unwarranted, since God has made sure to build in certain mechanisms that protect against permanent or disastrous perturbations. A secular version of this argument is implied by some interpretations of so-called Gaia theory. According to this view, 'the sum of all complex feedbacks between life, atmosphere, rocks, and water give rise to Gaia, the evolving,

\footnotetext{
${ }^{19}$ We are grateful to an anonymous reviewer, who pointed this out to us. Kearns (2007: 114) argues that 'economics and the support of free enterprise and capitalism' are 'perhaps the most significant factor in the opposition to global warming' among religious groups in the US. However, as noted by Wilkinson (2012: 190, footnote 13), scholars are in disagreement about which factor is chief in explaining the religiously motivated (Christian) opposition against climate change action: theology, economics, or perception on the role of law in environmental management.
} 
self-regulating planetary entity that has maintained habitable conditions on the surface of our planet over vast stretches of geological time' (Harding, 2009). ${ }^{20}$

The idea that there are more important goals than saving the climate system (lack of moral relevance and cost-benefit argument), is embraced by Christians and atheists alike. Although gay marriage and abortion are seldom referred to as important problems to combat in secular contexts, poverty certainly is. In fact, one common secular argument against greenhouse gas mitigation is the negative impacts that a redistribution of money and attention to greenhouse gas emissions reductions will have on poverty and human development. Bjorn Lomborg is one representative of this view. (For a critical discussion, see Gardiner, 2011: 281-284).

\section{Openings? Compatibility with climate adaptation action}

In this section, we consider to what extent, if any, the arguments discussed above are consistent with support for climate adaptation action. If any are, it could present an opportunity to involve more conservatives, if not in greenhouse gas mitigation, then at least in the adoption and enforcement of risk-reducing adaptation measures. It would, of course, be naïve to think that hardcore opponents of climate action - the Cornwallists would take any notice of this. However, someone who is inclined to take the Cornwallist arguments seriously but is not (yet) a dedicated climate action opponent, might still find climate adaptation measures somehow justifiable.

If you believe, as some conservative evangelicals do, that the risks of climate change are relatively small and that God will at some point put all things right again, it is unlikely that you would support any long-term adaptation measures, especially if

\footnotetext{
${ }^{20}$ See also Erica Lea on Sallie McFague's Christian ecofeminist theology, https://eewc.com/christianecofeminist-theology/ (accessed 30 January 2019).
} 
taken by the government. However, some support might nevertheless be gained for measures that are taken by individuals to protect against negative weather events, provided that they do not cost much (i.e. they constitute a prudent response in accordance with Luke 14:28), are designed so as to protect human well-beings, and do not divert the attention away from issues that are considered to be more important from a moral and spiritual point of view.

That the costs must be reasonably low follows from the cost-benefit argument. The argument does not imply that environmental or climate change regulations ought never to be enacted. The argument merely says that such policies should not be enacted when the costs exceed the benefits, and that in the case of greenhouse gas emissions reductions this is clearly the case.

That the climate measures must be designed to safeguard human well-being follows from the enrichment argument and to some degree from the anti-paganism argument. Both arguments reject far-reaching climate action, albeit on slightly different grounds. According to the anti-paganism argument, focusing intensely on preserving the climate system constitutes a form of idolatry; it 'serves the creature rather than the Creator' and, thus, violates the absolute divorce believed to exist between God and the natural world. According to the enrichment argument, far-reaching climate measures conflict with the elevated standing of humans within the creation, including their right, even responsibility, to enrich the creation through use of fossil fuels. Arguably, adaptation action is more easily reconcilable with both arguments, at least to the extent that it focuses on human well-being. Focusing on human well-being does not constitute idolatry in the same way as focusing on the environment would do, as witnessed by conservative Christians' attention to poverty eradication (see also moral relevance argument). Similarly, when directed towards human well-being, adaptation does not 
conflict with the elevated standing of humans in the creation. On the contrary, it is fully compatible with an anthropocentric view of humanity's place in the natural order.

\section{Conclusions}

We conclude that the arguments of the core group of Christian conservatives studied in this paper - the Cornwallists - could be labelled climate change denialist, since several of them build on premises that conflict with climate science. However, our analysis shows that the trend-attribution-impact denial framework, commonly applied in studies of climate science denial, fails to capture some of their arguments. The reason for this is that this opposition often rest on premises that render the science irrelevant. We therefore propose that the trend-attribution-impact framework should be supplemented with yet another category of denial, which we tentatively call 'relevance denialism'. Relevance denialists do not necessarily deny a certain scientific fact but question its normative significance. Relevance denialists can be found among groups other than the Cornwallists, who wish to downplay the climate issue for various reasons, not the least among defenders of the idea that economic growth is always a net positive.

\section{Acknowledgements}

The authors would like to thank a number of anonymous referees for their valuable comments and suggestions on how to improve the paper. The authors would also like to thank Sven Ove Hansson, Mikael Karlsson, Björn Lundgren, and the participants at the conference 'Philosophy, Politics, and Economics', held at London School of Economics and Political Science (LSE) on 7 Dec 2017, for their comments on previous versions of the manuscript. Remaining errors are our own. 
This research was funded by Formas - The Swedish Research Council for Environment, Agricultural Sciences and Spatial Planning under grant 211-2014-595.

\section{Figures}

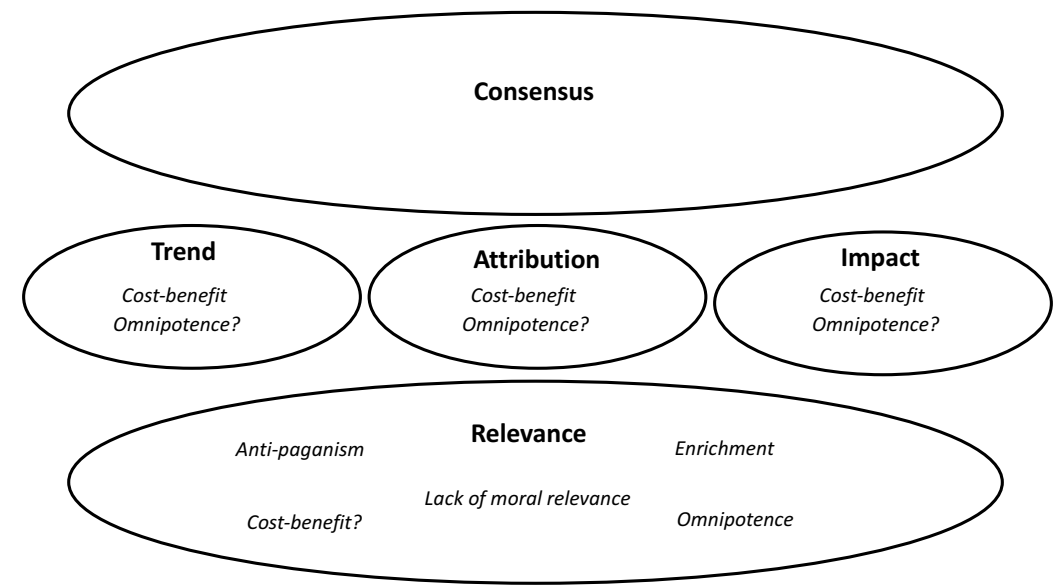

Figure 1. Overview of the conceptual landscape of the climate denialist arguments.

\section{References}

Agliardo, M. 2014. 'The U.S. Catholic response to climate change'. In R. G. Veldman, A. Szasz, and R. Haluza-DeLay (eds.), How the World's Religions are Responding to Climate Change, pp. 174-192. London: Routledge.

Allen, B. 2007. 'Falwell says global warming tool of Satan'. Published 01.03.2007, http://www.ethicsdaily.com/falwell-says-global-warming-tool-of-satan-cms-8596 (accessed 30 January 2019). 
Bean, L. and S. Teles. 2015. Spreading the Gospel of Climate Change: An Evangelical Battleground. New America, https://static.newamerica.org/attachments/11649spreading-the-gospel-of-climatechange/climate care11.9.4f0142a50aa24a2ba65020f7929f6fd7.pdf (accessed 30 January 2019).

Bebbington, D. W. 1989. Evangelicalism in Modern Britain: A History from the 1730s to the 1980s. London: Unwin Hyman.

Beisner, C. E. 1993. 'Are God's resources finite? A group of Christian leaders claim they are, but does the claim square with the evidence?'. World Magazine 8(27): 10-13, https://cornwallalliance.org/1993/11/evangelical-environmental-declaration-seeksconsensus-on-controversial-views/ (accessed 30 January 2019).

Beisner, C. E. 1997. Where Garden Meets Wilderness: Evangelical Entry into the Environmental Debate. With introduction by Rev. John Michael Beers. Acton Institute for the Study of Religion and Liberty and W. B. Eerdmans Publishing Company: Grand Rapids, Michigan.

Beisner, C. E. 2005. 'Biblical principles for environmental stewardship'. In R. W. Spencer, P. K. Driessen, and C. E. Beisner, An Examination of the Scientific, Ethical and Theological Implications of Climate Change Policy, pp. 13-19. Interfaith Stewardship Alliance.

Beisner, C. E. 2012. 'Gospel confusion in Christian environmentalism'. Published 29.05.2012, https://world.wng.org/2012/05/gospel_confusion_in_christian_environmentalism (accessed 30 January 2019). 
Beisner, C. E., P. K. Driessen, R. McKitrick, and R. W. Spencer. 2006. A Call to Truth, Prudence, and Protection of the Poor: An Evangelical Response to Global Warming, https://cornwallalliance.org/landmark-documents/a-call-to-truth-prudence-andprotection-of-the-poor-an-evangelical-response-to-global-warming/ (accessed 30 January 2019).

Carr, W., M. Patterson, L. Yung, and D. Spencer. 2012. 'The faithful skeptics: Evangelical religious beliefs and perceptions of climate change'. Journal for the Study of Religion, Nature and Culture 6(3): 276-299.

Cheaney, J. B. 2016. 'Doomsday report: What radical environmentalists always seem to miss about humanity'. Published 30.04.2016, https://world.wng.org/2016/04/doomsday_report (accessed 30 January 2019).

Christianity Today. 2008. Current Issues Bible Study Series: Creation Care. Christianity Today International.

Chryssavgis, J. 2007. 'Ecumenical Patriarch Bartholomew: Insights into an Orthodox Christian worldview'. International Journal of Environmental Studies 64(1): 9-18.

Cook, J., N. Oreskes, P. T. Doran, W. R. L. Anderegg, B. Verheggen, E. W. Maibach, J. S. Carlton, S. Lewandowsky, A. G. Skuce, S. A. Green, D. Nuccitelli, P. Jacobs, M. Richardson, B. Winkler, R. Painting and K. Rice. 2016. 'Consensus on consensus: A synthesis of consensus estimates on human-caused global warming'. Environmental Research Letters 11: 048002.

Cornwall Alliance 2000. The Cornwall Declaration on Environmental Stewardship, https://cornwallalliance.org/landmark-documents/the-cornwall-declaration-onenvironmental-stewardship/ (accessed 30 January 2019). 
Cornwall Alliance 2006. An Open Letter to the Signers of 'Climate Change: An Evangelical Call to Action'. Burke, VA: Cornwall Alliance.

Cornwall Alliance 2013. The Biblical Perspective of Environmental Stewardship: Subduing and Ruling the Earth to the Glory of God and the Benefit of Our Neighbors. Winona: International Church Council Project and Burke, VA: Cornwall Alliance. Cornwall Alliance 2019. The Cornwall Stewardship Agenda. Burke, VA: Cornwall Alliance.

Daley Zaleha, B. and A. Szasz. 2015. 'Why conservative Christians don't believe in climate change'. Bulletin of the Atomic Scientists 71(5): 19-30.

Danielsen, S. 2013. 'Fracturing over creation care? Shifting environmental beliefs among evangelicals, 1984-2010'. Journal for the Scientific Study of Religion 52(1): $198-215$

ECI (Evangelical Climate Initiative) 2006. Climate Change: An Evangelical Call to Action, http://www.christiansandclimate.org/statement/ (accessed 30 January 2019).

Ecumenical Patriarch Bartholomew 2016. Message by His All-Holiness Ecumenical Patriarch Bartholomew to the UNFCCC COP22 Session, Marrakech, Morocco, November 7-18, 2016.

Edvardsson Björnberg, K., M. Karlsson, M. Gilek and S. O. Hansson. 2017. 'Climate and environmental science denial: A review of the scientific literature published in 1990-2015'. Journal of Cleaner Production 167: 229-241. 
Engels, A., O. Hüther, M. Schäfer and H. Held. 2013. 'Public climate-change skepticism, energy preferences and political participation'. Global Environmental Change 23(5): 1018-1027.

Gardiner, S. M. 2011. A Perfect Moral Storm: The Ethical Tragedy of Climate Change. New York: Oxford University Press.

Haag, A. 2006. 'Church joins crusade over climate change'. Nature 440: 136.

Harding, S. 2009. Animate Earth: Science, Intuition and Gaia. Totnes: Green Books.

IPCC (Intergovernmental Panel on Climate Change) 2014. Climate Change 2014:

Synthesis Report. Contribution of Working Groups I, II, and III to the Fifth Assessment Report of the Intergovernmental Panel on Climate Change [Core writing team, R. K. Pachauri and L. A. Meyer (eds.)]. Geneva: IPCC.

Kearns, L. 2007. 'Cooking the truth: Faith, science, the market and global warming'. In L. Kearns and C. Keller (eds.), Ecospirit: Religions and Philosophies for the Earth, pp. 97-124. New York: Fordham University Press.

Kearns, L. 2011. 'The role of religions in activism'. In J. S. Dryzek, R. B. Norgaard and D. Schlosberg (eds.), The Oxford Handbook of Climate Change and Society, pp. 414428. Oxford: Oxford University Press.

Lausanne Movement 2011. The Cape Town Commitment, https://www.lausanne.org/content/ctc/ctcommitment (accessed 30 January 2019).

Lieberman, B. 2012. 'The Catholic Church and climate change'. Yale Climate Connections, https://www.yaleclimateconnections.org/2012/02/the-catholic-church-andclimate-change/ (accessed 30 January 2019). 
Matthews, P. 2015. 'Why are people skeptical about climate change? Some insights from blog comments'. Environmental Communication 9(2): 153-168.

McCammack, B. 2007. 'Hot damned America: Evangelicalism and the climate change policy debate'. American Quarterly 59(3): 645-668.

McCright, A. M., S. T. Marquart-Pyatt, R. L. Shwom, S. R. Brechin and S. Allen. 2016. 'Ideology, capitalism, and climate: Explaining public views about climate change in the United States'. Energy Research and Social Science 21: 180-189.

Mirus, J. 2007. 'Global warming and Catholics'. Published 22.07.2007, http://www.catholicculture.org/commentary/otc.cfm?id=157\&repos $=6 \&$ subrepos $=2 \& \mathrm{~s}$ earchid=1767485 (accessed 30 January 2019).

Mirus, J. 2012. 'Global warming, global repentance'. Published 01.03.2012, http://www.catholicculture.org/commentary/otc.cfm?id=939\&repos=6\&subrepos $=2 \& \mathrm{~s}$ $\underline{\text { earchid=1767485 }}$ (accessed 30 January 2019).

Mongrain, K. 2017. 'The burden of guilt and the imperative of reform: Pope Francis and Patriarch Bartholomew take up the challenge of re-spiritualizing Christianity in the Anthropocene age'. Horizons 44: 80-107.

Morrison, M., R. Duncan and K. Parton. 2015. 'Religion does matter for climate change attitudes and behavior'. PLOS ONE 10(8): e0134868.

NAE (National Association of Evangelicals) 2015. Caring for God's Creation: A Call to Action, https://www.nae.net/caring-for-gods-creation/ (accessed 30 January 2019).

Nagle, J. C. 2008. 'The evangelical debate over climate change'. University of St. Thomas Law Journal 5(1): 53-86. 
Peifer, J. L., E. H. Ecklund and C. Fullerton. 2014. 'How evangelicals from two churches in the American southwest frame their relationship with the environment'. Review of Religious Research 56(3): 373-397.

Pew Research Center 2015. Religion and Science. Washington: Pew Research Center.

Poortinga, W., A. Spence, L. Whitmarsh, S. Capstick and N. F. Pidgeon. 2011.

'Uncertain climate: An investigation into public scepticism about anthropogenic climate change.' Global Environmental Change 21(3): 1015-1024.

Pope Francis 2015. Encyclical Letter Laudato Si' of the Holy Father Francis (On Care for Our Common Home), published 24.05.2015.

Purdy, J. 2015. After Nature: A Politics for the Anthropocene. Cambridge, MA: Harvard University Press.

Rahmstorf, S., 2004. The Climate Sceptics. In Weather catastrophes and climate change - Is there still hope for us? Munich Re, pp. 76-83, http://www.pikpotsdam.de/ stefan/Publications/Other/rahmstorf_climate_sceptics_2004.pdf (accessed 30 January 2019).

Reed, C. 2007. 'The Rev Jerry Falwell - Rabid evangelical leader of America's "moral majority"”. The Guardian 17.05.2007, https://www.theguardian.com/media/2007/may/17/broadcasting.guardianobituaries (accessed 30 January 2019).

Roberts, J. 2007. 'Falwell was “old guard” of religious right'. CBS News 16.05.2007, https://www.cbsnews.com/news/falwell-was-old-guard-of-religious-right / (accessed 30 January 2019). 
Schaefer, J. 2014. 'Religious motivation for mitigating human-forced climate change:

Scientifically informed, politically astute, and collaborative.' International Journal of

Climate Change Strategies and Management 6(1): 34-46.

Schlitt, M. 1992. Umweltethik. Philosophisch-ethische Reflexionen-Theologische Grundlagen - Kriterien. Schöningh: Paderborn.

Smith, N. and A. Leiserowitz. 2013. 'American evangelicals and global warming'. Global Environmental Change 23(5): 1009-1017.

Wilkinson, K. K. 2012. Between God and Green: How Evangelicals Are Cultivating a Middle Ground on Climate Change. Oxford University Press, New York. 